\title{
Trend Analyses of Parameters of Equations for Sender Node Energy Savings Achievable in ubicomp MANETs using Location-Aware Transmission.
}

\author{
M. Kaleem GALAMALI, Assoc. Prof Nawaz MOHAMUDALLY
}

\begin{abstract}
Location-Tracking and correspondingly applications on it along with new functionalities are being developed in the field of ubicomp [30-66]. MANET transmission strategies are also subject to research. An area missing in the field of ubicomp is the software engineering approaches of metric development, analysis and modelling for predictability purposes and better gearing of future research investments. The particular area of concern here is energy considerations in ubicomp. A previous research [14] was carried out to assess how much energy savings can be achieved by a sender node in location-aware MANET transmission and the corresponding model was put forward as exponential.
\end{abstract}

In this paper, the next set of question investigated is legitimately put forward as: "What are the trends of variation observable within each parameter of the exponential equation obtained for metric SES [14] over varying node densities?"

The need for studying the behaviour of components of an applicable model and successively model the behaviour of each component mathematically is felt required since it involves a lot of work and results may be used by designers to better predict ubicomp behaviour and formulate correspondingly better architectures. This paper is a follow-up of previous papers [1-14].

Key terms: Ubicomp- Ubiquitous Computing, MAUCMobile and Ubiquitous Computing, ES- Energy Savings, SES- Sender ES, MANET- Mobile Adhoc Network, CBRConstant Bit Rate.

M. Kaleem GALAMALI,

University of Technology Mauritius (student) Mauritius

Assoc. Prof Nawaz Mohamudally University of Technology Mauritius, Mauritius

\section{Introduction}

Many factors affect energy consumption in MAUC [2]. Another pertinent factor is type of transmission; One such type is MANET transmission and correspondingly, the subsequent pertinent factor is node density. An attempt has been made in previous research [14] to find a particular trend/model which depicts energy savings that can be reached by senders in MAUC (SES) to rate the effectiveness of location- aware MANET transmission strategies compared to the theoretical/empirical models derived in simulations. The model put forward for metric SES was the exponential model of form:

$$
F(x)=a * \exp (b *(x-c))
$$

Here the equation for this model comprises of three parameters: $\mathrm{a}, \mathrm{b}$ and $\mathrm{c}$. the next probing that is required is the study of modelling of the parameters of the equation obtained above and successively forming the model of variation for each parameter.

The key contributions of this paper is the establishment of the trend of variation for each parameter of the equation of the model of equation for metric SES presented in previous paper [14] by using the same tabular data presented in that same paper, covering node numbers 7 until 56. Availability of these data will in turn help designers to better understand the evolution and predictability of ubicomp environment in a manner that this understanding may be adapted into a software program for future adaptability requirements of ubicomp following different scenarios possible. The rest of this paper is organised as follows: section 2Parameter Trend Analysis- Metric SES, section 3Conclusion and References.

\section{Parameter Trend Analysis - Metric SES.}

\subsection{General Procedure Adopted.}

The tabulated data for each parameter of equation of model for SES is plotted onto gnuplot and analysed graphically with support from smooth bezier plot. General observations, for each such graph obtained is reported. Several equations of fits have been attempted and a summary is reported for each SES parameter of equation. Ultimately, choice has been based firstly on least reduced chi-square value and secondly on most plausible extendability produced at node numbers 80 , 100 and 120. Finally, the values of parameters for each SES parameter of equation is also noted.

\subsection{Trend Analysis - SES parameter " $a$ ".}

The curve obtained depicts an increasing tendency with a decreasing rate of increase reaching a maximum value 
and then decreases very smoothly and slowly. The graph is not symmetrical.

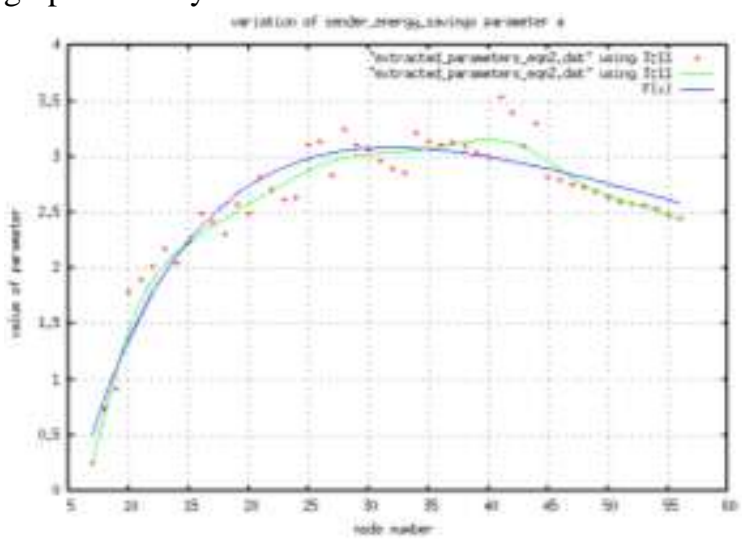

Figure 1: SES parameter a

A summary of potentially applicable equations of trend is provided below:

1. $F(x)=\left(\left(a * x^{d}\right) /\left(\exp \left(\left(b * x^{h}\right)+c\right)\right)\right)$ $+(f / x) \star \log (x)$

Ch_sq $=0.0514985 \quad \mathrm{~F}(80)=1.493684$

$\mathrm{F}(100)=0.898 \quad 490 \quad \mathrm{~F}(120)=0.519443$

2. $F(x)=\left(\left(a * x^{2}\right) /\left(\exp \left(\left(b * x^{h}\right)+c\right)\right)\right)$ $+(f / x) \star \log (x)$

Ch_sq $=0.0438668 \quad \mathrm{~F}(80)=1.836032$

$\mathrm{F}(100)=1.348 \quad 354 \quad \mathrm{~F}(120)=0.979047$

3. $F(x)=\left(\left(a * x^{3}\right) /\left(\exp \left(\left(b * x^{h}\right)+c\right)\right)\right)$ $+(f / x) \star \log (x)$

Ch_sq $=0.0443925 \quad \mathrm{~F}(80)=1.9155$

$\mathrm{F}(100)=1.465550 \quad \mathrm{~F}(120)=1.118004$

4. $F(x)=\left(\left(a * x^{4}\right) /\left(\exp \left(\left(b * x^{h}\right)+c\right)\right)\right)$

$+(f / x) * \log (x)$

Ch_sq $=0.0447282 \quad \mathrm{~F}(80)=1.918$

$\mathrm{F}(100)=1.4745 \quad \mathrm{~F}(120)=1.132254$

5. $F(x)=\left(\left(a * x^{5}\right) /\left(\exp \left(\left(b * x^{h}\right)+c\right)\right)\right)$ $+(f / x) * \log (x)$

$$
\begin{array}{ll}
\text { Ch_sq }=0.0612825 & \mathrm{~F}(80)=0.313 \\
\mathrm{~F}(100)=0.1849 & \mathrm{~F}(120)=0.049307
\end{array}
$$

6. $F(x)=\left(\left(a * x^{4}\right) /\left(\exp \left(\left(b * x^{h}\right)+c\right)\right)\right)$ $+\left(f / x^{2}\right) * \log (x)$

Ch_sq $=0.0433888 \quad \mathrm{~F}(80)=1.908409$

$\mathrm{F}(100)=1.452688 \quad \mathrm{~F}(120)=1.105 \quad 501$

7. $F(x)=\left(\left(a * x^{4}\right) /\left(\exp \left(\left(b * x^{h}\right)+c\right)\right)\right)$ $+\left(f / x^{3}\right) \star \log (x)$

Ch_sq $=0.0491963 \quad \mathrm{~F}(80)=1.667523$

$\mathrm{F}(100)=1.149452 \quad \mathrm{~F}(120)=0.787498$

\section{Choice of best fit for SES parameter a}

The equation in part 6 above has been selected because of both smallest reduced chi-square value obtained and good extendability. The parameters for best fit are:

$\mathrm{a}=2.275, \mathrm{~b}=6.68684, \mathrm{c}=-2.46916, \mathrm{f}=-16.802, \mathrm{~h}$ $=0.251917$.

\subsection{Trend Analysis - SES parameter " $b$ ".}

Generally the curve obtained for node number 8 and above depict an increasing tendency with a small decrease in rate of increase. It is possible that for node number 7, a different behaviour is obtained since the plot appears as an outlier.

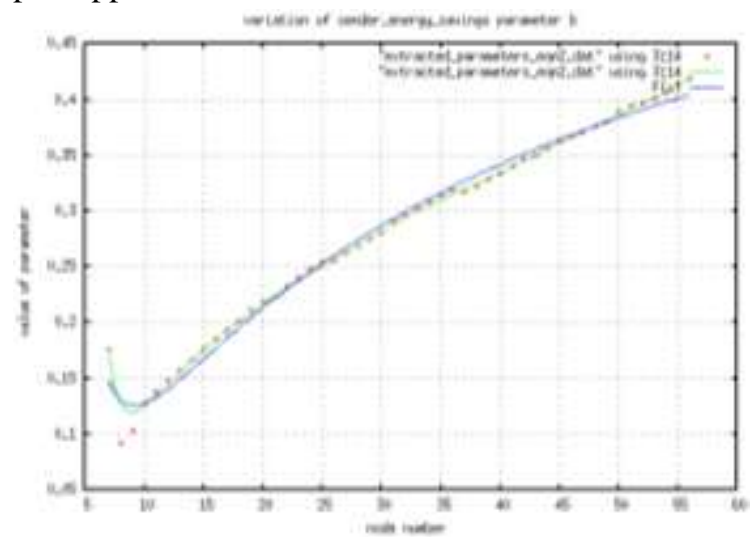

Figure 2: SES parameter $b$

A summary of potentially applicable equations of trend is provided below:

1. $F(x)=d * x+f$

Ch_sq $=0.000203527$

2. $F(x)=a * \exp (b *(x-c))+d$

Ch_sq $=0.000216866$

3. $F(x)=a * \log (b *(x-c))+d * x$

Ch_sq $=0.000138148$

4. $F(x)=a * \log (b *(x-c))+d$

Ch_sq $=0.000136938$

5. $F(x)=a^{*} \log (b *(x-c))+d * x+f$

Ch_sq $=0.00014105$

6. $F(x)=a * x^{0.5} * \log (b *(x-c))+d$

Ch_sq $=0.0001418$

7. $F(x)=a * x^{-0.5} \star \log (b *(x-c))+d$

$\mathrm{Ch}_{\overline{\mathrm{n}}} \mathrm{sq}=9.99445 \quad \mathrm{~F}(80)=0.468$

$\mathrm{F}(100)=0.506 \quad \overrightarrow{\mathrm{F}}(120)=0.536$

\section{Choice of best fit for SES parameter b}

The equation in part 7 above has been selected because of both smallest reduced chi-square value obtained and good extendability. The parameters for best fit are:

$a=-0.84466, b=4.1453, c=3.3687, d=1.01263$

\subsection{Trend Analysis - SES parameter " c".}

The curve depicts an increasing tendency from node number 7 until about node number 22 with decreasing rate of increase, after which the curve tends to flatten. 


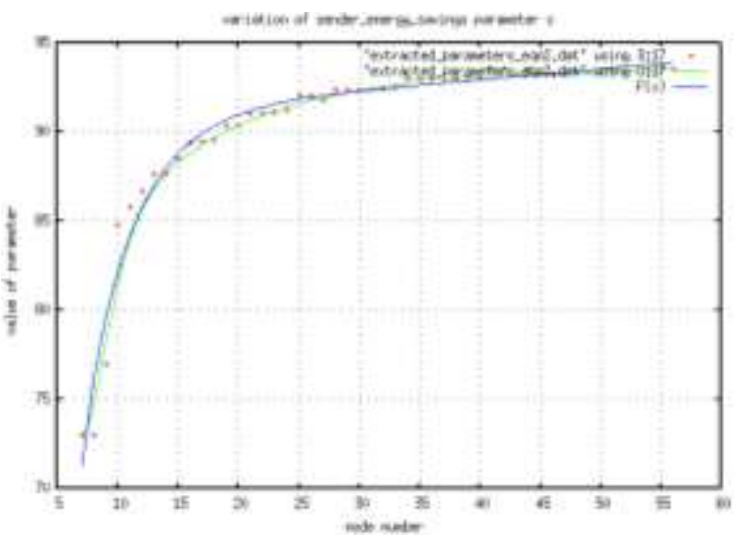

Figure 3: SES parameter c

The summary of potentially applicable equations is given below:

$$
\begin{aligned}
& \text { 1. } F(x)=a * \exp (b *(x+c))+(d / x)+f \\
& \text { Ch_sq }=0.752005 \quad \mathrm{~F}(80)=95.022617396 \\
& \mathrm{~F}(100)=95.756213552 \quad \mathrm{~F}(120)=96.295471578 \\
& \text { 2. } F(x)=a * \exp (b *(x+c))+\left(d * x^{-1.5}\right)+f \\
& \text { Ch_sq }=0.835083 \quad \mathrm{~F}(80)=92.703836399 \\
& \mathrm{~F}(100)=92.062709654 \quad \mathrm{~F}(120)=91.361384306 \\
& \text { 3. } F(x)=a * x * \exp (b *(x+c))+\left(d * x^{-1}\right)+f \\
& \text { Ch_sq }=0.764577 \quad \mathrm{~F}(80)=95.131321686 \\
& \mathrm{~F}(100)=95.744845642 \quad \mathrm{~F}(120)=96.161046600 \\
& \text { Ch_sq }=0.783841 \\
& \text { Ch_sq }=0.75723 \\
& \mathrm{~F}(80)=95.085660843 \\
& \mathrm{~F}(100)=95.749790884 \\
& \mathrm{~F}(120)=96.211888541
\end{aligned}
$$

\section{Choice of best fit for SES parameter $c$}

The equation in part 5 above has been selected even if its reduced ch_sq is second smallest; its extendability is more stable. The parameters of best fit are:

$\mathrm{a}=11.1576, \quad \mathrm{~b}=-0.0935466, \mathrm{c}=1.81928, \mathrm{~d}=-$ $281.322, \mathrm{f}=98.5549$

\section{Conclusion.}

This piece of study was aimed at and has developed the models of trend of the parameters of equations for the metric SES in a MANET topography of $300 \times 300 \mathrm{~m}^{2}$. The models put forward will help to study MANETs for MAUC environment from a software engineering perspective. The models put forward in this paper, are mathematical in nature and can be mapped onto programming algorithms. The experiment was carried out in NS-2 over Linux. The plottings and "fit" attempts were done in gnuplot. Best fit was evaluated from reduced chi-square values and best extendability of equations obtained.

Assumptions stated in previous paper [14] hold here also. Gnuplot is also assumed as appropriate. The intrinsic constructs of gnuplot is not questioned here.

Further work identified remain: formulating methods of predictability for metric SES and its trend and reporting observations of certain critical values identified.

\section{References}

[1] M. Kaleem GALAMALI, Assoc. Prof Nawaz MOHAMUDALLY, Towards Dependable Pervasive Systems-A Position and Vision Paper, CEET 2014

[2] M. Kaleem GALAMALI, Assoc. Prof Nawaz MOHAMUDALLY, Model of Energy Savings achievable with Location-aware Node-to-Node Transmission in UbiComp , CEET 2014

[3] M. Kaleem GALAMALI, Assoc. Prof Nawaz MOHAMUDALLY, Model of Energy Savings achievable with Location-aware Node-to-Node Transmission in UbiComp Using Location Refresh Intervals, CEET 2014

[4] M. Kaleem GALAMALI, Assoc. Prof Nawaz MOHAMUDALLY, Model of Energy Savings achievable with Location-aware Transmission in UbiComp Using Relays, CEET 2014

[5] M. Kaleem GALAMALI, Assoc. Prof Nawaz MOHAMUDALLY, Mathematical modeling of need of exact number of relays to ensure seamless mobility in mobile computing, CEET 2014

[6] M. Kaleem GALAMALI, Assoc. Prof Nawaz MOHAMUDALLY, Modelling of need for multiple relays for ensuring seamless mobility, CEET 2014

[7] M. Kaleem GALAMALI, Assoc. Prof Nawaz MOHAMUDALLY, Investigation of prominence of placements of relays in a ubicomp topography,

[8] M. Kaleem GALAMALI, Assoc. Prof Nawaz MOHAMUDALLY, Model of energy savings achievable with location-aware transmission in ubicomp using optimised number of relays.

[9] M. Kaleem GALAMALI, Assoc. Prof Nawaz MOHAMUDALLY, Investigation of Prominence of Placements of Optimised Number of Relays in a Ubicomp Topography using Location-Aware Transmission, CEET 2015.

[10] M. Kaleem GALAMALI, Assoc. Prof Nawaz MOHAMUDALLY, Extending Node Battery Availability in Ubicomp with Location-Aware Transmission, CEET 2015.

[11] M. Kaleem GALAMALI, Assoc. Prof Nawaz MOHAMUDALLY, Extending Node Battery Availability in Ubicomp with Location-Aware Transmission using Location Refresh Intervals, CEET 2015.

[12] M. Kaleem GALAMALI, Assoc. Prof Nawaz MOHAMUDALLY, Extending Node Battery Availability in Ubicomp with Location-Aware Transmission using Uniformly Placed Relays, CEET 2015.

[13] M. Kaleem GALAMALI, Assoc. Prof Nawaz MOHAMUDALLY, Extending Node Battery Availability in Ubicomp with Location-Aware Transmission Using Optimally Placed Relays, CEET 2015.

[14] M. Kaleem GALAMALI, Assoc. Prof Nawaz MOHAMUDALLY, Model of Sender Node Energy Savings Achievable with Location-Aware MANET Transmission in Ubicomp. ACCN 2016

[15] M. Kaleem GALAMALI, Assoc. Prof Nawaz MOHAMUDALLY, Model of Overall Node Energy Savings Achievable with Location-Aware MANET Transmission in 
Ubicomp. ACCN 2016

[16] M. Kaleem GALAMALI, Assoc. Prof Nawaz MOHAMUDALLY, Model of Sender Node Extra Energy Savings Achievable in MANET Against Direct Node-toNode Transmission Using Location-Aware Transmission in Ubicomp. ACCN 2016

[17] M. Kaleem GALAMALI, Assoc. Prof Nawaz MOHAMUDALLY, Model of Overall Node Extra Energy Savings Achievable in MANET against Direct Node-toNode Transmission Using Location-Aware Transmission in Ubicomp. ACCN 2016

[18] M. Kaleem GALAMALI, Assoc. Prof Nawaz MOHAMUDALLY, Model of Energy Consumption Ratio Achievable in MANET Using Location-Aware Transmission in Ubicomp. ACCN 2016

[19] M. Kaleem GALAMALI, Assoc. Prof Nawaz MOHAMUDALLY, Model of Minimum Energy Consumption Ratio Achievable in MANET Using LocationAware Transmission in Ubicomp. ACCN 2016

[20] M. Kaleem GALAMALI, Assoc. Prof Nawaz MOHAMUDALLY, Model of Maximum Energy Consumption Ratio Achievable in MANET Using LocationAware Transmission in Ubicomp. ACCN 2016

[21] M. Kaleem GALAMALI, Assoc. Prof Nawaz MOHAMUDALLY, Model of Overall Energy Consumption Fairness Ratio Achievable in MANET Using LocationAware Transmission in Ubicomp. ACCN 2016

[22] M. Kaleem GALAMALI, Assoc. Prof Nawaz MOHAMUDALLY, Model of Overall Energy Consumption Fairness Proportion Achievable in MANET Using LocationAware Transmission for Ubicomp, CEET 2016

[23] M. Kaleem GALAMALI, Assoc. Prof Nawaz MOHAMUDALLY, Model of Minimum Fairness Proportion Achievable in MANET Using Location-Aware Transmission for Ubicomp, CEET 2016

[24] M. Kaleem GALAMALI, Assoc. Prof Nawaz MOHAMUDALLY, Model of Maximum Fairness Proportion Achievable in MANET Using Location-Aware Transmission for Ubicomp, CEET 2016

[25] M. Kaleem GALAMALI, Assoc. Prof Nawaz MOHAMUDALLY, Model of Sender Fairness Proportion Achievable in MANET Using Location-Aware Transmission for Ubicomp, CEET 2016

[26] M. Kaleem GALAMALI, Assoc. Prof Nawaz MOHAMUDALLY, Model of Distance Travelled by packets in MANETs using Location-Aware Transmission for Ubicomp, CEET 2016

[27] M. Kaleem GALAMALI, Assoc. Prof Nawaz MOHAMUDALLY, Model of Maximum CBR Distance Travelled by packets in MANETs using Location-Aware Transmission for Ubicomp, CEET 2016

[28] M. Kaleem GALAMALI, Assoc. Prof Nawaz MOHAMUDALLY, Model of Minimum CBR Distance Travelled by packets in MANETs using Location-Aware Transmission for Ubicomp, CEET 2016

[29] M. Kaleem GALAMALI, Assoc. Prof Nawaz MOHAMUDALLY, Model of Range CBR Distance Experienced by Transmissions in MANETs using LocationAware Transmission for Ubicomp, CEET 2016

[30] Markus Bylund and Zary Segall, Towards seamless mobility with personal servers, 2004.

[31] Masugi Inoue, Mikio Hasegawa, Nobuo Ryoki and Hiroyuki Morikawa, Context-Based Seamless Network and Application Control, 2004

[32] Xiang Song, Umakishore Ramachandran, MobiGo: A Middleware for Seamless Mobility, College of Computing Georgia Institute of Technology, Atlanta, GA, USA, August 2007

[33] Budzisz, Ferrús, R., Brunstrom A., Grinnemo, K, Fracchia, R., Galante, G., and Casadevall, F. Towards transport-layer mobility: Evolution of SCTP multihoming, March 2008

[34] Paul Dourish \& Genevieve Bell, Divining a digital future, 2011.

[35] Xiang Song, Seamless Mobility In Ubiquitous Computing Environments, PhD Thesis, Georgia Institute of Technology, August 2008

[36] Kevin O Mahony, Jian Liang, Kieran Delaney, User-Centric Personalization and Autonomous Reconfiguration Across
Ubiquitous Computing Environments, NIMBUS Centre Cork Institute of Technology, Cork, Ireland, UBICOMM 2012

[37] Pablo Vidales, Seamless mobility in 4G systems, Technical Report, University of Cambridge, Computer Laboratory, Number 656, November 2005

[38] João Pedro Sousa and David Garlan, Aura: An Architectura Framework for User Mobility in Ubiquitous Computing Environments, School of Computer Science, Carnegie Mellon University, USA, August 2002

[39] Dennis Lupiana, Ciaran O'Driscoll, Fredrick Mtenzi, Defining Smart Space in the Context of Ubiquitous Computing, Dublin Institute of Technology, Ireland, Special Issue on ICIT 2009 Conference - Web and Agent Systems, 2009

[40] N.S.V.Shet1, Prof.K.Chandrasekaran2 and Prof. K.C.Shet3, WAP Based Seamless Roaming In Urban Environment with Wise Handoff Technique, International Journal of UbiComp (IJU), Vol.1, No.4, October 2010

[41] Yipeng Yu Dan He Weidong Hua Shijian Li Yu Q Yueming Wang Gang Pan, FlyingBuddy2: A Braincontrolled Assistant for the Handicapped, Zhejiang University, UbiComp'12, September 5-8, 2012.

[42] Jing Su, James Scott, Pan Hui, Jon Crowcroft, Eyal de Lara Christophe Diot, Ashvin Goel, Meng How Lim, and Eben Upton, Haggle: Seamless Networking for Mobile Applications, 2007

[43] Rui Han, Moustafa M. Ghanem, Li Guo, Yike Guo*, Michelle Osmond, Enabling cost-aware and adaptive elasticity of multi-tier cloud applications, Future Generation Computer Systems, 2012

[44] Byrav Ramamurthy, K. K. Ramakrishnan , Rakesh K. Sinha, Cost and Reliability Considerations in Designing the NextGeneration IP over WDM Backbone Networks, 2012.

[45] Bhavish Aggarwal, Aditya Akella, Ashok Anand, Athula Balachandran, Pushkar Chitnis, Chitra Muthukrishnan, Ram Ramjee and George Varghese, EndRE: An End-System Redundancy Elimination Service for Enterprises, NSDI 2010, San Jose, CA

[46] Ashok Anand, Vyas Sekar and Aditya Akella, SmartRE: An Architecture for Coordinated Network-wide Redundancy Elimination, SIGCOMM 2009, Barcelona, Spain

[47] John Breeden II, "Smart-phone battery life could double without better batteries", Nov 14, 2012

[48] Andy Boxall, "When will your phone battery last as long as your kindle", December 5, 2012

[49] Imielinski, T. and Navas, J.C. (1999). GPS-based geographic addressing, routing, and resource discovery. Comms. ACM Vol. 42, No. 4, pp. 86-92.

[50] Hightower, J. and Borriello, G. (2001). Location Systems for Ubiquitous Computing. IEEE Computer, Vol. 34, No. 8, August, pp. 57-66.

[51] Harter, A., Hopper, A., Steggles, P., Ward, A. and Webster, P. (2002). The Anatomy of a Context-Aware Application. Wireless Networks, Vol. 8, No. 2-3, Mar-May, pp. 187-197.

[52] Hightower, J., Brumitt, B. and Borriello, G. (2002). The Location Stack: A Layered Model for Location in Ubiquitous Computing. Proceedings of the 4th IEEE Workshop on Mobile Computing Systems \& Applications (WMCSA 2002), Callicoon, NY, USA, June, pp. 22-28.

[53] Graumann, D., Lara, W., Hightower, J. and Borriello, G. (2003). Real-world implementation of the Location Stack: The Universal Location Framework. Proceedings of the 5th IEEE Workshop on Mobile Computing Systems \& Applications (WMCSA 2003), Monterey, CA, USA, October, pp. 122-128.

[54] Ko, Y., \& Vaidya, N. H. (2000). Location-aided routing (LAR) in mobile ad hoc networks. Wireless Networks, 6(4), 307-321.

[55] Liao, W.-H., Tseng, Y.-C., \& Sheu, J.-P. (2001). GRID: a fully location-aware routing protocol for mobile ad hoc networks. Telecommunication Systems, 18(1), 37-60.

[56] Kuhn, F., Wattenhofer, R., Zhang, Y., \& Zollinger, A. (2003). Geometric ad-hoc routing: of theory and practice. In Proceedings of the ACM (PODC'03) (pp. 63-72). 
[57] Jiang, X., \& Camp, T. (2002). Review of geocasting protocols for a mobile ad hoc network. In Proceedings of the Grace Hopper Celebration (GHC).

[58] Ko, Y. \& Vaidya, N. H. (1999). Geocasting in mobile ad hoc networks: location-based multicast algorithms. In Proceedings of the IEEE (WMCSA'99) (pp. 101).

[59] Mauve, M., Fuler, H., Widmer, J., \& Lang, T. (2003). Position-based multicast routing for mobile ad-hoc networks (Technical Report TR-03-004). Department of Computer Science, University of Mannheim.

[60] Xu, Y., Heidemann, J., \& Estrin, D. (2001). Geographyinformed energy conservation for adhoc routing. In Proceedings of the ACM/IEEE (MOBICOM'01) (pp. 70-84).

[61] Hu, Y.-C., Perrig, A., \& Johnson, D. (2003). Packet leashes: a defense against wormhole attacks in wireless ad hoc networks. In Proceedings of the INFOCOM' 03 (pp. 19761986).

[62] Patwari, N., Hero III, A. O., Perkins, M., Correal, N. S., \& O’Dea, R. J. (2003). Relative location estimation in wireless sensor networks. IEEE Transactions on Signal Processing, 51(8), 2137-2148.

[63] Baldauf, M., Dustdar, S., \& Rosenberg, F. (2007). A Survey on Context Aware Systems. International Journal of Ad Hoc and Ubiquitous Computing, Inderscience Publishers. forthcoming. Pre-print from: http://www.vitalab.tuwien.ac.at/ florian/ papers/ijahuc2007.pdf

[64] Hong, D., Chiu, D.K.W., \& Shen, V.Y. (2005) Requirements elicitation for the design of context-aware applications in a ubiquitous environment. In Proceedings of ICEC'05 (pp. 590-596).

[65] Neeraj Tantubay, Dinesh Ratan Gautam and Mukesh Kumar Dhariwal, A Review of Power Conservation in Wireless Mobile Ad hoc Network (MANET)", International Journal of computer Science Issues, Vol 8, Issue 4, No 1, July 2011.

[66] Wenrui Zhao, Mostafa Ammar and Ellen Zegura, "A Message Ferrying Approach for Data Delivery in Sparse Mobile Ad Hoc Networks", MobiHoc'04, May 24-26, 2004, Roppongi, Japan.

About Author (s):

Associate Professor Nawaz Mohamudally works at University of Technology, Mauritius (UTM) and has undertaken supervision of MPhil/PhD Students for many years.

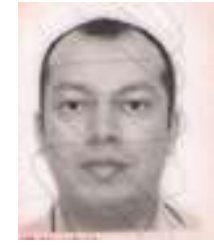

M. Kaleem Galamali is a part-time student (achieved M Phil Transfer on 28.10.2014, currently $\mathrm{PhD}$ student) at UTM under supervision of A.P. Nawaz Mohamudally. 